O'erwhelmed by Noise: Soundhouses and Sonic Experiments in Ben Jonson's

\title{
Epicene
}

\section{Frost, BS}

http://hdl.handle.net/10026.1/10601

\subsection{3/shb.2017.0044}

Shakespeare Bulletin

Johns Hopkins University Press

All content in PEARL is protected by copyright law. Author manuscripts are made available in accordance with publisher policies. Please cite only the published version using the details provided on the item record or document. In the absence of an open licence (e.g. Creative Commons), permissions for further reuse of content should be sought from the publisher or author. 


\section{"O'erwhelmed with Noise": Sound-Houses and Sonic Experiments in Ben}

Jonson's Epicene

BRIONY FROST

University of Exeter

In his unfinished text, New Atlantis (1627), Sir Francis Bacon indulges in a fantasy of dedicated spaces in utopian colleges in which

[w] practice and demonstrate all sounds and their generation ... represent Small Sounds as Great and Deepe; Likewise Great Sounds, Extenuate and Sharpe; Wee make diuerse Tremblings and Warblings of Sounds, which in their Originall are Entire ... Wee haue also diuerse Strange and Artificiall Eccho's, Reflecting the Voice many times ... rendring the Voice, Differing in the Letters or Articulate Sound ... Wee haue also meanes to conuey Sounds in Trunks and Pipes, in strange Lines, and Distances (182).

These "Sound-Houses" are imaged as part of a sensory laboratory, in which all senses can be stimulated and tested. Such a learning environment is predicated upon a preCartesian philosophy that "all knowledge begins with sense experience" (B. Smith, Key of Green 100). Prevalent in early modern medical and philosophical discourses that followed the doctrines of Aristotle and Thomas Aquinas, this theory distinguished between two types of senses, both recognised as "preliminary to the intellect": the internal and the external senses (Aquinas 1: 411). The scholars of the colleges serve as loose figures for these sensory groups and their connecting pathways. The "demonstration of all sounds and their generation" is practiced upon the "Pioneers"; it reflects the stimulation of one of the external senses-hearingwhich "establish[es] contact [thereby blurring the boundaries between auricular and 
tactile impressions] with the world through sensation" (Griffin 149, emphasis added). ${ }^{1}$ This excites the humors, which move the passions, and the response is documented by the "Compilers" or internal senses: common sense, imagination, and memory. These internal senses allow the externally perceived sensations to be received, often synaesthetically, by the "Benefactors," the rational soul, "to "draw out of them things of use and practice for man's life and knowledge" (Bacon, New Atlantis 184; Griffin 149).

Scholarship on early modern sensory experience has increasingly focused on illuminating the period's cultural understanding of the sensorium through performance: how it is presented and prioritized, understood, and enacted on stage in diverse, isolated, and interactive, temporally specific ways. Site-specifics, too, are being probed: the prospects for reconstructing through theatrical representations the early modern urban soundscape and its subcultures, and the visual, aural, olfactory, and tactile environments - particularly Blackfriars and the Globe-in which the performances took place. Ben Jonson's Epicene, famous for its "sonic theme," is often found among the focal points in these studies for its generous depiction of London acoustics, its class-stratified and gendered sonic communities, and its portrait of the ideal auditor (Cockayne, Hubbub 109). ${ }^{2}$ More recently, though, studies have turned toward the sensible body which, due to the receptive quality of sense perception, is open and vulnerable in the "wild and complex sensorium" of the theater (Karim-Cooper 269). "The presentation of drama," writes Farah Karim-Cooper, "seem[s] to have the capacity to infect or affect its spectators, potentially producing changes in their humoural constitution, their emotional states, and even their behaviour" (269). To my knowledge, less attention has been given in Epicene to how the play's sensory bodies, both real and imagined, are affected by the specific 
soundscape of its venue: how the bodies in the auditorium and on stage physically perceive, receive, and process sound, and how this informs and is informed by the geographic and architectural parameters of Whitefriars.

In this article, I propose that the venue's sonic environment, both indoor and outdoor, played a vital role in the play's performed experience and interpretation. Fascinated, even fixated, as he was on the competition between seeing and hearing a play, I will suggest that in Epicene Jonson uses the play's venue to anticipate Bacon's fantasy of futuristic colleges, setting up within its performance space a series of sonic experiments that test the limits of human perception, response, and rationalization to extend a vision of principally acoustic but ultimately multisensorial pedagogy through which the rational souls in attendance might "draw out ... things of use and practice for man's life and knowledge" (Bacon, New Atlantis 184). Through a partial reconstruction of the Whitefriars theater's internal acoustics, and using historical and archaeological records to identify the district's principal soundmarks, this article aims to show that the playhouse was central to Epicene's sonic theme, serving as an acoustic laboratory in which the audience are taught to negotiate the place of the individual within their sonic community.

\section{The Theater as Soundhouse}

In 1609/10 when Epicene premiered, Whitefriars was a new indoor playing space and the performances it hosted indicate that it offered a novel forum in which to audit a play (Keenan 65). Knowledge of the theater is limited in comparison to our understanding of Blackfriars or the Globe and much is based on educated speculation; even its location and, consequently, its exact dimensions are still subject to critical debate. Historical endeavors to place the theater within the Whitefriars precinct rely 
heavily on a c. 1627 survey of the property block acquired by Richard Morrison after the Dissolution and reproduced by A. W. Clapham during his early-twentieth-century archaeological excavations of the site. Candidates put forward for the performance space have been "The Scullery," the old monastic refectory marked as "My Lord's Cloister," and "The Hale." The first site has been widely discredited; however, strong cases continue to be made for the latter two. Among the most current of these, architectural evidence uncovered by Nick Holder prefers "the Hale," a "converted monastic library building to the west of the cloister" ("Re: Whitefriars"); this contends an equally plausible case based on textual evidence and stagecraft put forward by Kerry Steele in favor of the refectory (Steele 100-21). ${ }^{3}$ Some attention must be given to both these locations to guide a study of their acoustic properties and the impact this would have had on Jonson's dramaturgy in Epicene and the play's own soundscape.

"The Hale," which "join[ed] the cloisters to the western boundary of the precinct," was a "long ... building," with a maximum internal space of ninety-seven feet by seventeen feet, curtailed by a "passage through ... its west end" that would have reduced its longitudinal dimension to around ninety feet (Holder, "Medieval Friaries" 21; Holder, "Re: Whitefriars"; I. Smith 168). The refectory is slightly shorter but is more than double the width, measuring eighty-five feet by thirty-five feet. These sites may usefully be compared with three other indoor venues: the two Blackfriars theatres and St Paul's. The latter, traced to a central hall on the upper floor of a two-storey almonry in St Paul's church, has been estimated at twenty-nine by forty feet. It is much the smallest and squarest of the venues, though its length exceeded its width confirming the general trend toward rectangular or "shoeboxshaped" halls, which are known-broadly speaking - to offer the best unenhanced 
distribution of sound (Ermann 87). ${ }^{4}$ Both of the Whitefriars venues are decidedly more rectangular in shape.

The Hale bears some resemblance to Farrant's Blackfriars: at twenty-six feet in width, the latter is understood (as far as it may be known) to be the narrowest of the indoor venues and was reportedly rather cramped (Steele 117). By contrast, Burbage's Blackfriars, with dimensions of forty-six feet by sixty-six feet has been called "very different" from the refectory (Munro, Children 23); but, of the three options, is closest to it with regard to proportions. Although approximately five feet narrower than the second Blackfriars theater, the refectory still appears to have been relatively spacious. The 1609 Chancery suit (Andrews v. Slater) concerning a failed investment in the Children of the King's Revels describes the building "the rooms of which ... are thirteen in number, three below and ten above; that is to say, the great hall, the kitchen by the yard, and a cellar, with all the rooms from the east end of the house to the Master of the Revels' office, as the same are now severed and divided" (qtd. in Wickham et al. 270). If the refectory was able to host so many rooms once subdivided it is more capacious than the Hale, closer to the size of the highly successful second Blackfriars. Its believed dimensions would place it, according to Steele, in between those of the two Blackfriars venues (117).

Scholarly opinion currently favors Steele's perspective. Holder's case for the former library and his reconstruction of its performance space is anchored in matching the 1608 investment contract describing the players' venue to the 1627 survey, a logistical breakdown of its accessibility from the nearby streets and, less encouragingly, a note that the frater "had been demolished by the time of the c. 1627 survey and is therefore less convincing" ("Re: Whitefriars"). If Collier's notoriously dubious reference to a 1616 survey in New Facts Regarding the Life of Shakespeare 
can be permitted at all, the remark that "the raine hath made its way in [to the abandoned refectory-theatre] and if it bee not repaired, it must soone be plucked downe or it will fall," is plausible given that over a decade had elapsed between the departure of the children's company and the Morrison survey (6).

Steele's argument for the wider venue draws on Inigo Jones's plans for an unrealized theater, which demands a width of thirty-seven feet, and some (rather crude) calculations about the amount of stage space required to host the most "extravagantly crowded scenes" in the Whitefriars canon, predominantly those from the King's Revels repertoire (138). She cites among her examples The Two Maids of Mortlake, in which "at least twenty players, or 'so many as may be' $\left(\mathrm{H} 3^{\mathrm{r}}\right)$, and a large banquet table accompanied by at least eight chairs or stools, share the stage" and, from the Queen's Revels, A Christian Turned Turk wherein sixteen characters, "four of whom lay cold upon the stage," and a "small banquet" are called for (140). As Jones's plans are for a purpose-built space, and sixteen players, suitably blocked, find space to inhabit St Paul's tiny stage at the conclusion of John Marston's What You Will, neither case is incontrovertible (Gurr, The Shakespearian Playing Companies 347). However, the practicalities of staging some of the dancing and combat scenes demanded by the children's repertoire make Steele's theory the more convincing.

Steele proposes that the Whitefriars playhouse was "most likely constructed in the former refectory," making use of "the upper floor of the building" (273). She goes on to suggest that

the auditorium was probably housed in a long, relatively narrow hall .... The stage would have been set across the width of the hall and flanked on either side by galleries. Each of these boxes would have consumed approximately seven and a half 
feet of the available thirty-five, leaving eighteen feet of horizontal space for the stage platform ... [which] may have projected as far as twenty-five feet into the auditorium ... [and] stood at least four feet above the floor (273).

She concurs with Jean MacIntyre that there would have been "three apertures; two ... flanking doors and the other ... a central opening" into a large discovery space extending back into the tiring house, with both the back and front hung with curtains (274). She challenges, however, MacIntyre's vision of a "reduced upper playing space" positing instead a "capacious" one that "extended laterally across much of the upper level or ... projected outward over the stage" to "accommodate eight or more characters on a square platform measuring six feet both ways," with a balustrade at the front and "supported by two sturdy stage posts near the downstage corners" (MacIntyre 3; Steele 274).

Further support for Steele's case may be garnered by considering the acoustic potential of the two spaces. Volumetric calculations of the sort proposed by Bruce Smith for Burbage's Blackfriars are not yet possible as either venue's ceiling height is theoretical at best (Acoustic World 214). Similarly, absorption coefficients cannot be accurately determined from the very limited references to stage properties and internal furniture available in the Whitefriars's lawsuits, the most detailed of which is the Chancery suit of 1609 (Hillebrand 223-25). However, some insights into the theater's acoustics have already been offered and it is possible to build upon them. Also arguing in favorr of the frater, Frances Teague notes that "Epicoene could only have been written for a small playhouse like the Whitefriars"; its "compact, enclosed auditorium would have amplified the trumpets, drums, and loud voices introduced as a device to annoy Morose" (176). The aural effect of the scene, forcing the audience 
to share in Morose's discomfort, would, she posits, have failed in a larger venue such as Blackfriars or the Globe where sound disperses more freely, "as would the humour of Epicoene's quiet whispering when Morose first inspects her in II.v" (176).

Shoebox-shaped halls became increasingly popular through the Renaissance and Restoration period for their capacity to provide both good sound coverage and "spatial impression" (Ermann 87). The general success of their sound transmission is due to human "bilateral symmetry," which "privileges sound arriving from the sides of our heads" (Ermann 87). Michael Ermann notes that "lateral reflections from the side walls trigger a binaural response, a sense that sound is coming from all directions and that we are immersed in sound" (87). Recent studies in architectural acoustics investigating the transmission of sound in a long narrow room with relatively "hard" surfaces have determined that, provided the "focus of interest [is] in the center of the short side" (where, as Andrew Gurr points out, the Whitefriars stage would logically be [The Shakespearean Stage 160]), relatively even sound coverage can be provided to the whole room "over the entire frequency range" (Long 617). There would inevitably be some falloff toward the rear of the room, since without compromising the spectatorship aspect by raising the stage above head-height, it is difficult to reduce the volume at the front of the room and raise it at the back of the room to fully equalize coverage. Nonetheless, in spaces without contemporary amplification devices, relatively narrow rooms with high ceilings have traditionally yielded the most effective sound coverage by relying on the room's naturally reflective properties to create a stereo effect (Long 698). The impact of this would, as Teague suggests, mean that in the frater-provided other internal conditions were favourablewhispers would carry relatively clearly to the whole audience, as would the sonic assaults visited upon Morose (176). 
While the Hale also offers a rectilinear space superficially conducive to good acoustics, the two sites are not equal. Holder's reconstruction suggests "an auditorium space of about $17 \mathrm{~m}$ by $5 \mathrm{~m}$ [fifty-six feet by seventeen feet], with space for twenty-one rows of seven seats, according to the seating module suggested by Irwin Smith," a gallery over the passage at the west end, and an "almost square" fifteen-by-seventeenfoot platform ("Re: Whitefriars"). MacIntyre's thesis of the wide discovery space and small upper platform is accepted, and a small tiring house (perhaps combined with a nearby kitchen facility) is proposed (3). Described in the Morrison survey as a stone building, the Hale is also known to have been a remnant of the medieval structure rather than part of the newer brick developments that were added after the Dissolution, "probably in the 1540s or 50s" (Holder, "Medieval Friaries" 416). Its walls would be highly reflective, returning ninety-eight to ninety-nine per cent of the energy waves that strike them (B. Smith, Acoustic World 214). Its single-glazed windows would be scarcely less so, bouncing back eighty to ninety per cent of the ambient sound (B. Smith, Acoustic World 214). A high-peaked ceiling is likely, based on other accounts of dissolved priories including Irwin Smith's reconstruction of Blackfriars (75).

This theoretical reconstruction of the Hale results in a very "live" (acoustically reflective) environment. Lots of hard reflective surfaces create problems with excess loudness and with slap echoes and flutter echoes, the latter of which are received as a "buzz-like" sound (Rossing 404; Wenger 17). The vaulted ceiling too generates unsatisfactory sound reflection distances; in his extensive study of the senses, Bacon observes that "in a Roome or in a Chappell ... vaulted ... in the Roofe, a Preacher cannot be heard so well, as in the like Places not so Vaulted" (Sylva Sylvarum 28). This would not have been compensated for by the room's other features. In such a 
narrow auditorium there would not have been space to accommodate much in the way of wood lining, which Bruce Smith notes as common to most indoor and outdoor theaters, or longitudinal seating galleries. Holder concedes that "it would be difficult to have longitudinal galleries without completely cutting off the sight-lines for the majority of the audience" ("Re: Whitefriars"). He suggests that a short gallery on one side may have been an option, but even then it would have to be situated above the stage, demanding the cramped upper playing area that does not fit well with Epicene's requirements for six to eight characters entering "above" in act four, scene five, nor the needs of other plays in the boy company's repertoire (Steele 236-38). While a gallery would be possible at the rear of the hall, the overall effect of this layout is a relative lack of wooden planes to provide the dispersal effect within the room, where sound is bounced from differently angled resonant surfaces, meaning that the space would have been compromised by unwanted reflections and its capacity to capture the ambient sound's “harmonic complexities” restricted (B. Smith, Acoustic World 209).

A theater in the Hale, then, would have been housed in a "bright, thin, and echoey" room that would make "dialogue ... more difficult to understand" (Kindig). It would suffer from excess loudness, particularly from musical instruments, and from errant echoes. Heavy drapes festooning the walls might have offered some sound absorption, but run the risk of absorbing too much of the lateral energy and deadening the acoustics. The significantly reduced seating capacity-170 to two hundred spectators, according to Holder's model — would have added to these problems; Leo Beranek and Tim J. Mellow observe that "shoebox-shaped halls with small seating capacities" have side walls that "reflect early sound nearer to the listener, which means that the reflections start masking the direct sound sooner" (482). The Hale is 
likely to have offered compromised intelligibility and tonality — and its restricted seating capacity would have brought in precious little revenue.

By comparison, the broader refectory space of the frater would retain the advantages of a shoebox-shaped room, "provid[ing] a sense of spaciousness ... and increas[ing] the apparent width of the sound source" to generate the desired "threedimensional" stereo-effect (Cavanaugh et al. 244). Greater width capacity permits the conventional wooden linings to be used and Steele's reconstruction envisages two longitudinal galleries on either side of the stage, probably containing wooden benches, plus a rear gallery (138). This raises the spectator numbers, the potential income, and the multiplicity of resonant surfaces. These surfaces help to diffuse standing waves throughout the room, evening out sound distribution and enabling the internal structure of the theater to act like the body of a guitar, resulting in "a plenitude of ... 'standing waves"” that auditors experience as "full, present sound, uniform throughout the listening space" (B. Smith, Acoustic World 209). Combined with the rectilinear shape, which "disperses sound waves throughout the room rather than focusing them in the centre," a propitious "round" sound is produced (B. Smith, Acoustic World 209).

Marshall Long provides an account of the acoustic experience within an eighteenth-century concert hall that is much closer in dimensions to the Whitefriars's frater than any of its immediate contemporaries. In a letter published on 29 June 1793 in The Berlinische Musikalische Zeitung, which described a concert there by wellknown violinist Johann Peter Salomon, the main concert hall of the Hanover Square Rooms was said to be "broader" and "better decorated" than the Stadt Paris in Berlin, while music there sounded "beautiful beyond any description" (Forsyth 38). The main concert hall measured thirty-two feet by seventy-nine feet and was "somewhat 
small for its intended capacity," which was eight hundred (Long 24). However, the reduced listening space was considered one of the venue's merits; its "low volume and narrow width ... provided strong reflections and excellent clarity, albeit at a somewhat loud overall level" (Long 24). While a multitude of other factors influence acoustic experience, a relatively densely populated, shoebox-shaped, even vaulted, hall has the potential to offer an impressive listening experience.

Finally, Steele's theoretical expanded upper playing area offers another significant acoustical effect. Large, sound-reflecting surfaces suspended over the main performing area are considered valuable in auditory terms as they create "foldback": "[immediate] reflections from the nearby surfaces to provide [performers] with the necessary sounds to enable them to hear themselves and each other" (Howard and Angus 319). Ideally, "the sound that is reflected back to the performers should be diffuse as this will blend the sounds of different instruments together for all the performers, while specular reflections can have hot and cold spots" (Howard and Angus 319). The combination of Steele's proposed broad upper platform, its posts, and the galleries ought to have provided sufficient onstage sound diffusion. Contrastingly, "shoebox halls without such reflectors often have less-than-ideal conditions on stage because of high stage ceilings," again indicating potentially problematic acoustics in the Hale (Cavanaugh et al. 140). The frater's internal onstage set-up, then, would have markedly "improved the ability of musicians [and performers] to hear one another," resulting in better acoustics not only for the audience but for those on stage (Cavanaugh et al. 140). All in all, the refectory offers the boys' company an acoustically superior venue.

\section{The Liberty as a "Place of Noise"}


Jonson's play relies not just on the new venue's internal acoustics but upon exploiting the full sonic potential of the liberty. Epicene begins with a lively exchange between the young city wit, Clerimont, and his Boy that immediately directs attention to the play's imagined location and the centrality of its soundscape to configuring (masculine) identity. Clerimont, who has composed a song about the fashions of (female) city-dwellers, requests that his boy sing and "let [him] hear it" (1.1.3). The Boy responds, "You shall, sir, but, i'faith, let nobody else ... [for] it will get you the dangerous name of a poet in town" (1.1.4-6). The exchange posits a "dangerous" or problematic relationship regarding man and place within the rapidly growing, increasingly gentrified and commodity-centric region known as "the town": a geographic area between "the court at Westminster and the City proper, to the east" (Zucker 100). Most of the play's action occurs "in private households on or near the Strand" (Zucker 100), with Clerimont's lodgings crucially described as being not "i[n] th' Strand" but within earshot of this wealthy thoroughfare (1.4.8, emphasis added)_perhaps within the adjoining Fleet Street or the White Friars' former precinct, which Gurr and Mimi Yiu identify as "roughly coincident" with the play's setting (Gurr, The Shakespearean Stage 118; Yiu, "Sounding” 74). Epicene's opening lines thus establish a dialogue between geographic and aural boundaries as mechanisms through which the identity of individuals and places are circumscribed.

Reputation, the Boy observes, is assessed upon being a source of sound versus being an auditor of sound, with the source being judged by his auditors based not only on what sound is being made but where that sound is being heard. Bruce Smith notes that, according to Stephen Feld, hearing is "an existential force ... in the shaping of cultures" (B. Smith, Acoustic World 47). Feld posits a reciprocal relationship between sense and place, noting that "as place is sensed, senses are placed; as places make 
sense, senses make place" (91). Consequently, as the Boy suggests, dwelling in a particular soundscape both shapes and is shaped by the way in which those dwellers, both auditors and noise-makers, hear themselves and their world. The next section of this article is dedicated to identifying the acoustic horizons of the Whitefriars neighborhood that were (re)created and called to mind in the playhouse, with a view to exploring how the district's aural landmarks could be used to probe the playgoers' sonic knowingness of themselves.

What did the Whitefriars district sound like? Situated within the ward of Farringdon Without, Whitefriars was one of two major London liberties that housed a private theater in the early Jacobean period. Bounded by Fleet Street to the north, Water Lane to the east, the Thames to the south, and the Inner Temple to the West, it was the former precinct of a Carmelite monastery, which had been dissolved in 1538 by Henry VIII. Like its dramatic partner in crime, Blackfriars, Whitefriars retained its sanctuary status after the Dissolution; as such, it became a "borderland whose legal parameters and privileges were open-ended and equivocally defined" (Mullaney 21). Inside the city but outside the lord mayor's jurisdiction, the liberties were selfgoverned: "responsible for their own policing ... trash pickup, and ... continence" (Bly 63). This, as is indicated by Morose's frantic attempts at urban zoning through the treatise he strikes with some of the city traders to curtail their cries, and his exiling of the "waits," "hammer-m[e]n," "brazier[s]" and "armorer[s]" from his parish, included the monitoring of noise $(1.1 .58,52,53)$.

The term noise covers a variety of imprecise and contradictory meanings in the early modern era. It could range from "any noise," according to Randle Holme, to sounds that were, according to Samuel Johnson, "[1]oud" or "clamourous; turbulent" (Holme 134). Among the more precise noise theorists of the time is Roger North. 
Cockayne observes that North's work identifies noise as sounds that "irritate the hearer because they [a]re irregular, intrusive, disturbing, distracting, inexplicable, or shocking" ("Cacophony" 36). He gives the example of sounds such as the "clapping of a door," which annoy because, unlike musical sounds, they have "unequal movements" and "uncertain periods"_- "every stroke is various, and depends not on the past, nor the future on that; and nothing of the measure is understood" (North 1011). Both early modern and contemporary noise theorists agree that sounds are more likely to be regarded as noise when they are "out of place" within a social or political context; that is, when they are heard in inappropriate places or at inappropriate times (Bailey 50). Sounds that interrupt concentration or sleep, or that disturb the sick, are particularly likely to be classed as noise. Tudor law recognized noise alongside heat and smell as sensory nuisances, but the authorities were limited as to what of the former could be tackled. As Cockayne points out

common noises associated with urban living, such as crying babies, barking dogs, and traffic, were not easily preventable, so there would have been little point in taking issue with them. As extraordinary sounds were, by definition, occasional and unpredictable, their prevention was also unfeasible. All the authorities could realistically try to deal with were those continual sources of noise such as rowdy alehouses, quarrelling spouses, and inappropriately located workshops (Hubbub 114).

Since, by 1600, Whitefriars's medieval right of self-regulation had enabled it to evolve into a place of "immunity for debtors, escaped felons, illegal foreigners, and sex workers" and where "cookshops and ale houses were open all night" (Bly 63), the combination of "wine ... Ryot ... Playes ... [and] Harlots" together with the precinct's 
proximity to the city walls, the commerce districts, and the Thames, would have given Whitefriars a voluminous soundscape (qtd. in Munro, Children 65).

The noisiness of Whitefriars is central to the sensory impact of Epicene in performance. While Lucy Munro has argued that Jonson "flirts with the locally specific" but "does not pin down the action of his play" ("The Whitefriars Theatre" 117), I want to suggest that he does. Although I agree that his physical landscape is not wedded to his words in the same way that Lording Barry's Ram Alley couples itself openly to a specific street within Whitefriars, Jonson goes further than "flirt[ing]" with the locally specific; he is actively courting it. The play, I will demonstrate, picks up the common city keynotes, yes, but it also takes some pains to single out a variety of soundmarks and sound-signals that are uniquely specific to the Whitefriars precinct - and that would be audible to the audience before, after, and during the performance.

The Boy's allusion to the hubbub of the Strand in the opening lines sets the scene for the introduction of Morose, the man who "can endure no noise" (1.1.142). Early on in their first exchange, Truewit and Clerimont greedily catalogue a clamor of the commerce district's audio-brands: the cries of "the fishwives" and "the orangewomen," whom Morose has persuaded (possibly financially) to silence; the resistance of the "chimney sweepers" and the Fleet Street-esque "broom-men," who will not be bribed, as well as the "costardmonger" whose shouts of "what do ye lack?" and “apples" can make Dauphine's uncle "swoon" $(1.1 .145,146,148,149)$. Morose has, the wits tell us, tried to fend off these "common noises"; he has caulked and sealed his property's apertures, detached his bell, and quilted his door (1.1.166). The play invites the audience to share in the wits" mockery of Morose's "ridiculous" "disease" 
(1.1.43), but even as it does so the playhouse's proximity to the Strand begins to expose the audience to the same sonic germs from which Morose recoils.

The plague of "common noises" in early modern London's commercial zones is attested to by Thomas Dekker, when the personified city of Westminster declares in The Dead Tearme (1608) that all the city walks are rife with "talking ... running ... riding ... clapping too of windows ... rapping at Chambers doors ... crying out for a drink ... buying up of meate, and ... calling upon Shottes" $\left(B 4^{\mathrm{r}}\right)$. The narrow urban streets, with their plaster-and-lathe buildings, created a "relatively reverberant environment," so that these "jingles, bangs, crunches, clops ... people talking ... [and] hawking their wares" would have carried down from the Strand on the northern perimeter of the Whitefriars precinct to within earshot of the theatre itself (B. Smith, Acoustic World 58). They were accompanied by a similar tribe of noisiness from Fleet Street, described as a place hectic with

horses, carts, mud, pick-pockets, drunks, brawls, beggars, barrels being rolled into taverns, porters bearing heavy loads, craftsmen working at their benches, criers and urchins hawking everything from broadsides to brooms, and housewives standing arms akimbo judging — and sometimes insulting — all who [dare] to enter their neighbourhood. (Bucholz and Ward 53)

In picking out of the commercial keynotes the specific calls of the traders, Jonson raises them to the level of sound-signals, attuning the attention to sounds that would ordinarily fade into the background as ignorable noise. The play's allusion to these sounds renders the audience not only conceptually aware of their presence nearby but actually able to hear them: the absence of Morose's effective soundproofing measures 
in the theater would enable some of these sonic equivalents of "neon flashing signs" to be carried in through the single-glazing and gaps under the doors from the nearby streets to infiltrate the wits' conversation and infect the audience's ears (B. Smith, Acoustic World 59, 64). ${ }^{5}$

The insidious presence of the real-life local street noise is further developed when the Boy tells us that, even before he began quilting and caulking, Morose "hath chosen a street to lie in so narrow at both ends that it will receive no coaches nor carts" (1.1.164-65), a place that Munro admits "would not be out of place in Whitefriars" ("The Whitefriars Theatre" 11). The Boy singles out amidst the common din the "thunder" of vehicular transport: predominantly traders" carts, and sedans and hackneys (Dekker, Seven Deadly Sins 57). The playgoers would have been familiar with the traffic sounds from their own daily experiences of it, but the presence of these sounds is pulled further into the foreground because many of the well-heeled playgoers would themselves have used hackneys and sedans to travel to the theater. Their routes would have been influenced by streets in the vicinity not wide enough to admit their carriages and the roar of wheels and the clatter of hooves as they travelled and bypassed other travelers. Even those who had not come by carriage would be affected by their own geographically and temporally recent encounters with the "outrageous" "noyse" of coaches (Peacham 8). Since the ruckus made by the coaches is described by Dekker as akin to the "world [running] upon wheels," it is likely that passing vehicles would also be audible through the theatre's apertures, stretching another tentacle of noisiness through into the auditorium as the performance progressed (Seven Deadly Sins 57).

The wits' exchange picks out a number of other soundmarks, some of which are broadly urban, many of which are locally unique. In the former category are 
church bells. Across the city, bells rang continuously for hortatory and narrative purposes. They "constituted a language and ... a system of communication," an "aural vocabulary ... with its own local variations": "some bells exhorted the hearer to perform an action: to pray, to attend services, to retire for the night, to start work or to stop it," while some "registered events or announced [local or national] news" (Sherman 37). Morose bemoans their relentlessness and the intensity of their aural demands, perhaps nodding to the fact that Whitefriars was within earshot of both the St Paul's and the Bow-Bell, the latter of which was "more famous then any other Parish Church of the whole Cittie" because its peals could be heard at such a great distance (qtd. in B. Smith, Acoustic World 53). The latter circumscribed an entire sonic community, including Whitefriars, since those within hearing range are known as cockneys - a reminder again of the permeability of neighborhood boundaries and that the Whitefriars's nation is not so separate from the rest of London as it sometimes appears. At the time of Epicene's performance, the plague bells were still tolling their farewells to the victims of the recent epidemic. The "reason of the sickness" and the associated "perpetuity of ringing" proves the final straw that inspires Morose to devise his "sonically hermetic room" (1.1.180; Zucker 101). Once again, the audience are reminded of the immediacy of the local, but now also the citywide, soundscape from which Morose is trying to retreat and the parts the bells direct them to play within it. This brings the pressure of daily routine, of the passage of hours in the day, of the days, and of lives, to bear upon them as sounds that they would have grown accustomed to as non-diegetic increasingly encroach into the diegetic.

As the play progresses and the theoretically soundproof space that Morose has created begins to break down, the audience's attention is steered to more and more city sounds within earshot of the playhouse. Truewit, when trying to dissuade Morose 
from the marriage he will eventually make, cheerfully references the "near[ness]" of the water as a suitable location for Morose to drown himself and escape the shackles of marriage (2.2.21). A common keynote in locations near the waterside, the play's specific allusion to it again lifts it to the level of a sound-signal, training the audience to become conscious again of the sloshing and slapping of the water. Later, the "Eastward Ho!" and "Westward Ho!" cries of the watermen are spoken of by Epicene (3.4.30-31). The watermen were known to be "rawcus figures," capable of generating with their oars and "telling [of] strange news" a "noise worse than confusion of Bedlam" (qtd. in Ellinghausen 98); their "boisterousness" (here meaning "clamourousness" [OED, "boisterousness" 9.b.]), she suggests, should "offend" her new husband's ear (2.2.30-31). Here the audience's consciousness of these sounds is urged towards annoyance with them. Those playgoers who did not travel by coach may well have come by water to the playhouse, mingling with the bellowing watermen, sploshing oars, and knocking boats, and would recall the racket and the jostling, the anxiousness that they might become subject to one of the frequent boating accidents, and the impatience of trying to reach the banks, so that their own recent journeys would stir their heartbeats, prickle their skin, and make their heads throb in empathy with Morose's discomfort. The "White Fryers [water] stayers" to the south of the playhouse are marked out on extant blueprints of the precinct after the Dissolution and would have provided a funnel for the noise of "its lapping tides [which were] audible along all the lanes and thoroughfares that led to the river," to carry strongly up to the theatre during the performance (Holder, "Medieval Friaries" 114).

The aural bombardment through the playhouse's doors and windows does not end here; local industries too are identified as sources of nearby noise. Located just 
beyond the city walls, Whitefriars was within a sonic collision zone for London's various intra- and extra-mural activities. Broadly speaking, inside the walls the exchanges of goods in the commercial zones dominated; outside, it was manufacturing processes. Beyond the walls were some of the noisiest industries in London: milling, tanning, butchering and brewing (Zucker 100; Merrit 184). These added to the general medley the scraping of skin, the banging and gushing of the execution methods, the shrieks of the animals, the chopping and carving of meat, the slaps, thump, or sploshes of carcasses being discarded into the river, and the boom of beer barrels rolling. The latter in particular is specific to Whitefriars. Amidst the properties within the friary that had not been repurposed into tenements after the dissolution was a tide-mill, which is invoked by Truewit and Morose during their incontinent rant about the barber's tattling after the Silent Woman is revealed to be thoroughly loquacious (3.5.91). It was attached to the former friary brewery, a few hundred feet from the frater in the south-east corner of the precinct. Both industries seem to have survived into the early seventeenth century (Holder, "Whitefriars" 124). These would have added the whir and whoosh of the water wheels, the grinding of grains and the splashing of liquids to the general rumpus.

Finally, a further soundmark specific to the Whitefriars precinct and audible from within the walls of the theater emerges through Jonson's allusion to the coughing priest, who oversees the marriage of Epicene and Morose. While the character is said to be taken from Libanius's Declamation 26, The Loquacious Woman, the explanation given by Jonson for the parson's cold is that he has been “sitting up late and singing catches with cloth workers" (Dutton, “Appendix C" 299; 3.4.11). A 1536 lease pertaining to redistributed properties within the old Whitefriars precinct indicates that a block of almshouses, to the south-east of the theater and not 
far from the water stairs, belonged to the Clothworkers' Company. It remained within their ownership until at least 1654 , when the infirmary property was also purchased by the company (Holder, "Medieval Friaries" 123). Their "catches" would, in the late afternoon and early evening, have infused the immediate soundscape of the playhouse; there may even have been someone among them with a cough.

Read against the archaeological and historical excavations of the theater's vicinity and the comings and goings of its men and daughters, then, Epicene's relationship to the locally specific is bordering on an engagement. It is not necessary that the exact noises referred to by the players would have been heard floating in from without at the moment to which they were referred, nor is it likely except by marvelous coincidence. What is important is that the sounds to which the play refers are distinct, local, and audible before, during, and after, the performance takes place. The play's repeated references to these external district noises attunes the audience's ears to the hereness and nowness of the acoustic amphitheater that Jonson was imagining. A brief survey of the play illustrates that it fluctuates between moments of intense sonic activity and comparative lulls that demands a constant reprioritizing of sonic focuses. At 2.1, 3.7, and 4.2, for example, come three significant crescendos, where the use of powerful instruments on stage would drown out any external noises. But there are notable lulls too, during many of which attention is called to the noises outside the theater. ${ }^{6}$ This zooming in and zooming out of focus between the playworld and the real world generates a state of sonic sensitivity in the audience that makes them acutely aware not only of noise in general, but of the noises of the district around them.

A dense and evolving residential and commercial neighborhood, the Whitefriars's soundscape was rapidly transforming in the year Epicene was 
performed. While "hi-fi" in comparison to the present day's markedly "low-fi" acoustic environment, the district must have been one in which the progressive movement from one to toward the other was increasingly apparent. Truly "hi-fi", soundscapes are, according to R. Murray Schafer, natural habitats in which "discrete sounds can be heard clearly ... sounds overlap less frequently" and "there is perspective-foreground and background" (43). "Lo-fi" soundscapes, however, suffer from "individual acoustic signals [being] obscured in an overdense population of sound ... [p]erspective is lost ... there is no distance; only presence"-a compressed wall of sound (43). Although the sonic parameters of the liberty were clearly still distinct enough to possess a unique and marketable local voice that Jonson could sell to the "men and daughters" of, and visitors to, the "Whitefriars' nation" (Epicene, Pro.24; Volpone 4.2.51), Epicene's efforts to bring out the area's "variety of noises" begin to give shape to a space where there is "crosstalk on all the channels" and where "in order for the most ordinary sounds to be heard they have to be increasingly amplified" (3.7.2; Schafer 43). The play's comprehensive catalogue of common noises establishes Whitefriars as a region playing host to a dynamic array not of broadband but disruptive, discontinuous and unpredictable sounds that sprawl out, and surge in, from beyond its architectural boundaries. This sort of sonic bleedover is described by writers such as Robert Hooke as "displeasing" because those within earshot find their aural apparatus "cannot keep up with the constant change of tuning required" (qtd. in Gouk 605). Both the displeasure and the sonic distortion have a discordant effect on the relationship between the individual and environment, which is hinted at with Clerimont, established through Morose, and cemented by the character of Sir Amorous La Foole. 
A new resident of the Strand, La Foole dwells in one of the large and ostentatious homes formerly occupied by bishops and wealthy Londoners that had been "subdivided and rented out to the rural gentry who had begun to converge on London" (Zucker 100). The knight is introduced as one who expressly chose the location "for the purpose" of leaning out of his tenement window to invite guests "aloud" to "plays and uppers," rather than following the conventional (and quieter) practices of visiting people privately or issuing written invitations $(1.3 .36,1.4 .77)$. He is known, moreover, for his highly inappropriate salutations, which he issues with complete disregard for the socially acceptable moment, casually addressing "a judge upon the bench and a bishop at the pulpit, a lawyer when he is pleading at the bar and a lady when she is dancing in a masque" (1.3.31-33). His soundmaking is always out of place within the social and political context, which is indicative of a breakdown of effective acoustic exchange in the city's soundscape to the extent that important communications, or "signals," are lost amidst the extraneous urban noise.

The sounds made by individuals in an environment, according to Barry Truax's detailed study of acoustic communication, take us back to the Boy's opening comments on reputation: an individual's soundmaking is shaped by, and shapes, the characteristics of their environment through processes of reflection and absorption, producing for the listener/soundmaker a simultaneous image of the self and environment (1: 20). This image relies on acoustic feedback for orientation and for awareness of the self in relation to others. A balance between listening and soundmaking, impression and expression is, Hildegard Westerkamp observes, critical to the individual's relationship to the soundscape as it can be seriously endangered by "noise, background music, and sound pollution in general" (qtd. in Truax 1: 23). While La Foole is heavily critiqued for his noisemaking by the other characters, his 
desperation to be heard demonstrates the degeneration of communicability within the city's social hub. To create a space for himself within the community, La Foole shouts over the existing din; the space is so busy he cannot simply passively appear there as he will not be seen or heard without exaggerated action on his part, so he is compelled actively to make himself heard, not by waiting for a turn to speak (there is unlikely to be one) but by amplifying his voice until it cannot be ignored.

The consequence, of course, is further disruption of the sonic environment, further enforced and displeasing changes in others' aural tuning, and a further breakdown in successful verbal communication, since his own noisemaking falls within three categories that disrupt it: "random sound[s] ... [potentially] varying in intensity and frequency"; sounds that, certainly at the specified moments, no one "wants to hear"; and sounds that "interfere with the reception of another [sound]" (Baldwin 7). La Foole's ill-timed salutations interrupt or distort other forms of communication, not only the hubbub of the streets but the official channels (the bench, the bar, the pulpit, and the court). As an outsider to the city, though, La Foole tailors his methods of communication to his environment based on the feedback he receives from it. Described scathingly by Truewit as a "windfucker" (2.1.77)—one who "fills himself with wind" (OED, "windfucker") — he is also "fl[ying] against the wind [of others] evermore," a symbol of a multi-district wide "linguistic adulteration that challenged acoustic reception and decreased the value of communication" both for the individual and within subcommunities across all levels of society (Nashe 49, Stanev 141).

This would have presented Jonson's audience with a challenge to their own understanding of their city's sonic boundaries. Having passed through these invoked environments en route to the playhouse, as the performance progressed the audience 
may have started to recognize in those around them, perhaps even in themselves, figures who contributed to the familiar din — and they would still have been able to hear it. An uncomfortable sense of listening to their own world as La Foole experiences it is established in the play's enforced tuning of the auditors' ears to the din of the nearby district and its capacity to adulterate the ordinary experience of listening to a play. As the scenes chop and change, now keeping one's attention on the performance, now calling attention to the insidious audibility of the city, the play disrupts its own mode of communication, creating an unstable and a times unpleasant listening experience.

Cockayne notes that "Morose dramatises the fact that personal boundaries of tolerability to noise were not uniform; he was an unusually sensitive character" (Hubbub 114). But in repeatedly drawing audience awareness to the semi-distant sounds of the district, Jonson singles out of its keynotes (background noise) its soundmarks ("community sounds" or aural landmarks) and "sound-signals" ("sounds to which the attention is particularly directed") (Schafer 91). The playwright thus serves, as Eleanor Decamp suggests, in a similar capacity to the character of Cutbeard-picking the ears of his audience in the manner of the barber (76). He opens up their aural passages beyond the range of their ordinary capacities and defamiliarizes their acoustic environment to the extent that he may infect them with the disposition of "a nervous, or anxious, or prepossessed listener" and they would "hear sounds which would otherwise have passed unnoticed" (Buckley 72; Cockayne, Hubbub 114). From the outset, the figurative wax is slowly and insidiously picked from the audience's aural apparatuses in anticipation of the play's forthcoming sound experiments, so that, little by little, Morose's misophony becomes contagious through the unpleasant overstimulation of the ears. In anticipation of further aural experiments 
to come, Jonson hyper-attunes his audience to what it means to hear this play about this metropolis in this metropolis.

\section{Jonson's Sonic Experiments}

In this final section of the article, I want to explore the ways in which Jonson uses the dynamic and complex sensorium of the Whitefriars theater to infect further the sensible bodies in his audience in order to effect potential changes in their behavior. As with the shifting sonic focuses that blur the non-diegetic into the diegetic, Jonson makes use of his stage properties, stagecraft, and the acoustic scope of the theater to conduct a series of sonic experiments that anticipate Bacon's sound-houses so that one may hear “diuerse Strange and Artificiall Eccho's, Reflecting the Voice many times ... rendring the Voice, Differing in the Letters or Articulate Sound ...” and sounds "convey[ed]... in Trunks and Pipes, in strange Lines, and Distances" to create a pedagogic effect (Bacon, New Atlantis 182).

If we return to the play's opening scene, it is apparent that Epicene sets up the first in a succession of sound-experiments that encourage the audience to question how they might best doctor themselves against a sonic sickness spreading like the plague through the precinct. The Boy is instructed to "[s]ing, sir"(1.1.20), though not to desist, allowing for his song to fade into the background and form a playful (and effeminizing) soundtrack to the arrival of Truewit, a man who speaks admiringly of his fellow wit's keeping a "mistress abroad" and the "ingle at home," before Clerimont summons the Boy's voice into the foreground again at $(24,23,85-86)$. Such ceaseless shifting of the sonic parameters accords with other aspects of the play's stagecraft. Throughout the play, the various actors and musicians are continuously moving in and out of earshot, and on and off the stage in terms of 
visibility but not audibility, making use of an array of instruments that dwarf, amplify, echo, and otherwise distort "the Originall" (the actors' speech) as well as referring to, listening for, and periodically drowning out the sounds that take place outside the walls of the theatre (Bacon, New Atlantis 41). This accords both with Jonson's reputation for prizing sound above spectacle, a perspective that precipitated his infamous quarrel with his masque-partner Jones and with his ability to speak "the language of architecture ... more fluently than any of his literary contemporaries" (Yiu, "Architecture" 304). It also enables him to maneuver his audience into the position of active auditors rather than passive spectators and hearers, who must filter out both the city's and the playworld's aural distractions and strain their ears for the sounds that matter.

To begin the investigation into the play's sonic experiments, I want to look at one of the rather neglected stage props that features in Epicene: Morose's speaking tube. While Morose's sound-stopping turban has received significant attention in critical studies, his speaking-tube has had less, yet the two work together in inextricable ways to frame Morose's relationship to his sonic environment: the relationship that the play is encouraging the audience both to laugh at, and empathise with. Described by Bacon as instruments that "preserueth [sounds] and causeth them to be heard further" (Sylva Sylvarum 22), speaking tubes carried an ambiguous status in the early modern era. Usually large indoor apparatuses, speaking tubes were used to transfer sound from place to place or room to room and, as such, tended to be set into a wall, such as Francis Godwin describes the Picts doing in order to communicate secretly “through each Tower and Castell” built along Hadrian's Wall and, later, as became normalized in the nineteenth century, to communicate privately and speedily between an employer's private rooms and the servants' quarters (qtd in Wolfe 112). 
Not yet commonly used for the latter purposes, large speaking tubes were recognized as part of ambassadorial machinery and promoted as faithful instruments that could overcome the fallibility of the human senses, to "disclose one mans mind unto another, and ... joyn them ... together" (qtd in Wolfe 112). They were seen by John Wilkins as capable of overcoming the impediments of distance, safely isolating the voice from ears not intended to hear it, protecting it from the intrusion of extraneous sound, which might corrupt the signal (qtd in Wolfe 112). On the other hand, like telescopes, automatic organs, and other mechanical devices such as Thomas Nashe's robotic birds, which satirize Italian artifice in The Unfortunate Traveller, they are often portrayed as foreign "craftie conveyances," part of a Machiavellian art of political manipulation and "devises and engynes" capable, as John Dee suggests, of “accomplish[ing] feats beyond human power" (qtd. in Wolfe 59). In both visions of the speaking tube, it is often seen as being used in conjunction with other encoded alien practices, such as smoke signals, "mystick Nods" and "feet [that] are made to speak, as well as walk" (Wilkins and Godwin, qtd. in Wolfe 112).

When Morose enters in act two, his trunk is immediately coupled with other such practices; his servants are banned from using speech: they must articulate themselves only in gesture "with [their] leg[s]," shrugs, nods, and hand movements (2.1.17). His dream is of being like "the Turk," who is "waited on by mutes; and all his commands so executed ... with silence" (2.1.29-32). He seeks, as Wilkins does in Mercury (1641) to "eliminate the need for [spoken] language altogether" and seems to share Wilkins' fantasy of erasing linguistic ambiguities - "is it not possible, that you should'st answer me by signs, and I apprehend thee, fellow?" (2.1.5-6)-by "resuscitating an Edenic language" of gesture that "“[m]ak[es] ... knowledge, too, intuitive" (Wolfe 112). His fantasy is not without merit in an environment where, as 
Dekker puts it, one constantly hears "such spitting, such talking, and such humming, every man's lips making noise, yet not a word to be understood, I verily believe that I am the Tower of Babel ... because there is in me such a confusion of languages" (The Dead Term 25). Morose's endeavors to restrict his servant, Mute, to communicating only with simple nods, bows, headshakes, and measures of time bespeak a wish to create a "world of absolute certainty" in one where the crosstalk on all channels constantly disrupts and distorts it (2.1.32; Levine 83).

Morose's transmission of his voice through a speaking tube is, in part, an extension of this striving for intuitive knowledge. He is also responding to the constant sonic bleedover of sounds within the city, against which he seals his ears when he walks abroad, and his doors when he is at home. His anxiety about confused communication and crosstalk, however, goes beyond endeavors to protect his own body. In his descriptions of speaking tubes, Bacon notes that those in England tended to be the ear trumpet, one of the earliest forms of hearing aid, which were portable. He pictures them in Sylva Sylvarum as "an instrument like a tunnel; the narrow part whereof may be of the bigness of the hole of ear, and the broader and much larger like a belt at the skirts," through which "any sound, abroad in the open air, will not be heard distinctly, from further distance than without that instrument" (22). As Morose enters carrying his tube in act two, it seems likely that his speaking tube is an ear trumpet, used to "help[...] somewhat those that are thick of hearing" (Sylva Sylvarum 23). If this is so, then in speaking through the trumpet Morose is also aiming to convey his voice at an enhanced volume within the same room as his servants and visitors. This suggests a response to his sonic environment that is not quite so far apart as it may initially seem from La Foole's. So determined is he not to lose his signal amidst the city din that shutting out other noises is not enough that he finds it 
essential both to protect his speech from extraneous noise and to prosthetically augment his companions' ears so that his communications are always the loudest thing that they hear. His misophony, then, goes beyond a simple fear of "harsh ... irksome" loudness that he wishes to exorcise with his turban and his quilted door (2.1.4-5). His speaking tube symbolizes a fear that those who dwell in the city will be "afflict[ed]" by permanent bodily damage as a result of the "discordant sounds" that the environment reflects back to them; he fears he may be, and that his companions are, at risk of aural disablement $(2.1 .4,3)$.

Morose's self-medication against this perceived physical threat is hardly a practice that the play promotes. His attempts to create a protective Edenic language are acutely biased, since he seeks to erase spoken communication on one side only and, on the other, to enhance the noise of his own voice, according it a superhuman, even godlike, status within his psuedoeremetic home. Stood upon the stage trumpeting down a speaking tube to silently gesticulating servants or bellowing down the equivalent of a loudspeaker to a prospective wife who answers him only in the softest of whispers, Morose's endeavors to improve his communications transforms them not into something lofty, but farcical. Consequently, he is heavily satirized by the other characters. Truewit and Clerimont's portrayal of Morose's turban as "Turkish" and his own praise of the "Italian and Spaniard" for their "frugal and comely gravity" sways the perception of both his instruments and his system of communication toward the realm of the alien and anticipates the artificial sonic transmissions later condemned by Bacon in New Atlantis $(2.1 .28,19)$. His response is also an unhealthy one. In his hatred of "living persons speaking to [him]," Morose's behavior becomes recognizable as a symptom of the disorder of the humors known as "melancholy" (Burton 84). The extremity of his reaction to the city's aural pollution 
is not natural or rational, but indicates a system that is sick and out of sync with itself. Rather than making himself well, he is making himself ill.

In spite of this, the play does validate Morose's anxieties, which Jonson achieves through conducting further sonic experiments on both his characters and his audience. One of the most notable experiments is the one imposed upon the cowardly knights, Sir Jack Daw and La Foole. Pursuing his exploitation of the permeability of the theater, Jonson's attention turns to the set itself. During their antics at the wedding party, the knights expose themselves as a "talking mole" and a windbag, "incapable of hearing through lies and rumours" and equally "incapable of telling the truth, as both ... announce that they have had sexual relations with Epicene" (2.4.137; Botelho 104). Truewit's prank, though, makes use of the theater's on- and offstage spaces to test the limits of the knights" flawed hearing. Describing a "gallery, or rather lobby," and a "couple of studies"- the stage areas beneath the above and behind the two smaller doors respectively_-into which he quickly sequesters Daw and La Foole, each on the pretext that the other is out for blood, Truewit's character uses the stage to play out a show of the walls having ears themselves (4.5.25). Jonson demonstrates the permeability of the set by having Truewit speak on stage and the knights respond, unseen, offstage behind the study doors. Here, the sense of hearing is deliberately divorced from the other senses as the other sensory elements of communication are removed. Bacon suggests that there is a "kind of Labour" in "listening after a Sound, that is heard with difficulty" and the knights are enticed into demonstrating exactly how idle they are at listening (Sylva Sylvarum 37).

The prank works on the premise that each of the confined knights thinks the other has come after him and is being restrained by Truewit, who speaks his half of the exchange on stage, while the knight hidden in the study speaks unseen. As both 
knights are locked in the studies, neither is present on the stage to be held back by the wit. In the tormenting of Jack Daw, Truewit advises him to "keep [his] breath close," a device that should both prevent the supposedly enraged la Foole from "hear[ing him] sigh" (4.5.77), thus discovering his whereabouts, to enable him to "Heare better" what is said between la Foole and Truewit as "Expiration['s] ... Motion is Outwards; And ... driveth away the voice, rather than draweth it" (Bacon, Sylva Sylvarum 37). Taking place beneath the capacious upper playing area posited by Steele, Truewit's monologue will be among the clearest moments of spoken speech in the play as the proximity of the overhead reflective surfaces amplify his voice. Since his voice must be heard clearly by Daw in order for him to respond — and the audience too will hear him clearly - the absence of la Foole's voice in the supposed exchange is thrown into sharp relief. Yet Daw not only hears Truewit loudly and ironically pleading for la Foole to calm down and hear him, he imagines he hears the invisible listener reply: "Did you hear him?" Truewit asks afterwards, and the cringing coward affirms that he did—fear's "quick ear" filling in an entirely inaudible and unspoken side to the "dialogue" (4.5.85). Furthermore, the muting of the knights' voices is one of the play's moments of sonic lull where the background urban audio track would creep in again through the theatre's apertures. The dangers of not listening properly, even to clearly audible sounds, against the backdrop of city noise demonstrates that hearing can be divorced both from the other external senses but also from most of the internal ones: only imagination processes the perceived information; recollection and common sense do not get to contribute.

The importance of multisensory processing, both external and internal, to man's understanding of himself and his environment is further developed through Morose's narrative and the play's use of crescendos. Escalating from the attention 
drawn to the permeability of the theater's walls, Jonson deploys the architectural aspects of the theatre to experiment upon his audience's aural apparatus. In the scenes in question, instruments are used to propel the noise within the theater up to a fever pitch. It begins with Truewit's wielding of a lone, tormenting trumpet within Morose's home at act two, scene one. Trumpets, which the play specifies, were rarely used in the indoor theatres. Trumpet sounds to have been deemed generally too loud for indoor playhouses and cornets were favored instead (Tosh and Smith). The abrupt, disruptive blasts of Truewit's trumpet anticipate the aural discomfort the audience will feel by the cacophonous climax of act four, scene two. By the time the engagement party is underway at act three, scene seven, the audience would already have been flinching at the sudden, unexpected bouts of noise-and it is noise, not music, that erupts from the stage instruments. When Truewit and Clerimont bring in the musicians to entertain the Collegiates with a "variety of noises," Clerimont commands them to "play, sirs, all of you," so that the musicians all strike up loudly and simultaneously (3.7.2). A brief exchange between Truewit and Clerimont follows in which the musicians strike up, are silenced, strike up, and are silenced again, creating the irregular pulses of noise that North identifies as annoying (10-11). They are also sensorially overwhelming.

Helkiah Crooke notes in Microcosmographia that sounds within a building are "contracted, gathered, or united, and therefore must needs mooue the Sense more fully" (700). At a recent Research-in-Action workshop in the Sam Wannamaker theatre, I experienced directly how effectively the overwhelming of external noises is achieved by a surround-sound effect created in a smaller, more angular space, without the use of amplification technology (Tosh and Smith). The audibility of instruments on the main stage was markedly more powerful, transmitted more clearly, quashed 
external industrial noises, and echoed for much longer than within the amphitheater space of the Globe. The trumpets in particular create greater resonance within the wooden structures than most other sounds. Morose's agonised complaints in act three, scene six that he is "o'erwhelmed with noise ... I feel an earthquake within myself for ' $\mathrm{t}$ " is not just a metaphor (3.6.3-4). Sound is known to "reverberate for longer in a tall narrow room than in a round, wide one" and this protracted reverberation is not only heard but felt as resonance as it is transmitted through the air and furnishings (Scott 2). The play's sonic crescendos blur the boundaries between sound and noise, between hearing and feeling, invoking a multisensory experience in which the acoustic effect resonates through the body to generate the earthquake sensation. The audience might also have felt themselves temporarily deafened, as the competing noises drown one another out, rebound off the multitude of reflective surfaces above and below the expanded upper playing area and from the seating galleries, and overwhelm the actors' voices.

Morose's fear of literal aural disablement becomes a temporary reality not just for the character but for the audience in these scenes. Bearing in mind, too, their situation within and upon the theater's vibrating wooden furnishings, and the smallness of the theatre that leaves them "cloistered in close proximity to the actors," the audience cannot help but "share in Morose's vexation" as the sonic assaults take place (Jackson 12). In spite of his ridiculousness, the joint encounter with such powerful multisensory stimulation yokes the audience's sympathies to Morose. This is, of course, essential to Jonson's final experiment upon his playgoers. This final experiment belongs to the play's super-plot: the revelation of Epicene's identity. The discovery that "she" is actually a "he" proves a climax to the play's "sonic overload" by exposing the shortcomings of not only many of the characters, but also the 
audience's own auricular capacities (Stanev 134). Harking back to Clerimont's Boy's comment that one may be judged as more or less of a man depending on what sound he may make as well as where that sound is heard, Morose's self-confinement within his eremitic home, his unfortunately phallic-looking prosthesis, and his marriage to the all-too-aptly-named Epicene result in a portrait of emasculation where he surrenders all attempts to protect his ears and submits to claiming sexual and ultimately economic disablement to escape the din. Mocked as a self-made martyr who believes that Dauphine and his company are "authors of all the ridiculous acts and monuments [that] are told of him," Morose proves that in shutting himself off from the sonic community he inhabits, he cuts himself off from his own masculine identity: the "ridiculous acts and monuments" told of him in the local community are not authored by himself but nonetheless reflect back to him his own "ridiculous" "disease" (1.2.9-10). He becomes the very emblem of what a man should not do.

But this experience is also perpetrated upon the audience. Capitalizing on the fact that "the ordinary playgoer does not constantly keep in his or her mind the crossdressing implications of the boys in women's parts" (Jardine 60), Jonson doublecrosses the audience by demonstrating that the acceptance of these theatrical conventions is a deliberate denial of information from the primary senses and a suspension of the usual processing accomplished by the internal senses. The conformity to social expectation in this instance results in denial of selfhood, a willful act of self-deafening, and semi-blindness, that accords with Morose's own. The play sets out to capture the disturbing and overbearing "sensory output" from the “metropolitan body," which "confuse[s], alienate[s], and sometimes even deprive[s] of agency and essence the sensorium, particularly debilitating the sense of hearing" (Stanev 134). As J. A. Jackson observes, "all of the noise and music must have led to 
a disorientation ... [about] where to focus their attention" (12). It is probable that this would have been compounded by the noises they themselves were generating. The restless and even rowdy behavior common to the outdoor theatres - from the "heaving and shoving ... itching and shouldering to sit by the women" of which Stephen Gosson complains to the "youths that thunder ... and fight for bitten apples" — was probably reduced by the absence of groundlings (Gosson 35; Shakespeare and Fletcher 5.4.65-66). However, the talking, eating, fidgeting, flirting, and even calling out to the actors on stage, like the "brave spark / That may judge for his sixpence," was part of the ordinary players-playgoer dynamic in the theater (Jonson, "To Mr. John Fletcher" lines 6-7). More work, beyond the scope of this article, is needed to flesh out the distinctions between audience behavior in the indoor and outdoor theaters, but the increased awareness of the playgoers' community and its physical proximity to the stage would have created a sense that the audience had "a clear view of what they are watching [and] advance[d] the illusion that [this] equal[led] additional insight or privileged knowledge" (Jackson 12). Yet what they have collectively seen and heard has, it turns out, been ignored. It is ultimately an act of lazy listening characteristic of those who go to a play to have their ears "tickled" or bowl first from "the Tauerne, then [to] the Ordinarie, then the Theater, and end in the Stewes" (Thomas Adams qtd. in Munro, Children 65). The audience have placed themselves at the same level as the misophonic Morose on the register of sonic (in)competence within the sounded margins of urban space.

The audience knew that Jonson had chosen a company of "in-betweeners" to take on the roles in this play (Brown 259). Though recent research has disproved an earlier belief that "there were no real women on the stage ... no 'real men' or even real men ... only boys" (Brown 259)—since certain actors such as Nathan Field, who may 
have played the titular Epicene, were adults in their twenties - the audience were aware that they were seeing not a mature adult acting company but a mixture of adolescents and young men, many of whom were garbed and, more importantly, speaking, as women. ${ }^{7}$ The costumes might, where necessary, mask physical distinctions; even so, the younger boys' voices would have "lacked the 'depth' provided by men's voices," filling the Whitefriars auditorium with a "piping, chattering, squawking" effect, akin to the screechy voices of young hawks that Rosencrantz imagines in Hamlet (B. Smith, Acoustic World 236; Ham. 2.2.336-38). Rather than the more mature voices creating "aural relief," as Smith suggests, research by Linda Phyllis Austern and Gina Bloom indicates that at least some of the older boys' voices would have been more unstable than their junior counterparts. The changes in the adolescents' vocal apparatus as they developed would have compromised their vocal control so that rather than producing voices that were "perfect, \& persuasive ... comely and audible," they would, particularly during moments of strenuous speaking, risk lapsing out of adult male voice into a "squekinge and slender," less audible one associated with childhood and with women (qtd. in Bloom 42; see also Austern). The overall effect of these "untuned" voices is of an unmanly listening experience (Jonson, Poetaster 5.2.222): “the body, as early modern men and women believed, [wa]s a microcosm with concordances to macrocosmic spheres of family, nation, and God, [and] a man unable to keep his voice from squeaking manifests a breakdown in patriarchal order" (Bloom 42). Against this backdrop of precarious vocality and unstable manhood, the artifice of a falsetto or the contrary depth of Epicene's voice as played by a known adult actor, should have seemed all the more noticeable and the prank apparent from the start-for those who were listening alertly. 
The punchline, though, relies on the expectation that no one was paying attention to the joke. Essentially, few fully adult men were speaking on stage and the audience already knew this. Yet they would have subscribed to a state of sensorial mutilation to fit in with the expectations of theatrical convention. The consequence of the play's auditory encounters is to demonstrate that "hearing is as frequently deluded as the sight" (Burton 314). And the deceit of the hearing is, according to Burton, in part the product of a "corrupt imagination": "as the fool thinketh, the bell clinketh," he quotes, noting that artificial devices and counterfeiters borrowing "all tones and tunes of men" may deceive the senses and lead to mistaken thinking (314). This is exactly what Jonson does and the delusion of the senses that occurs is aligned with sickly sensory deprivation, greasy ears, semi-blindness, and "air as corrupt as that wherewith you feed rumour" (5.4.238-39). The "voice of one's own mind," which Richard Dutton suggests ought to help navigate toward normality within the playworld, cannot wholly be trusted (Introduction 94).

To return to Bacon, he reports alongside his imagined Sound-Houses similar "houses of deceits of the senses; where we represent all manner of feats of juggling, false apparitions, impostures, and illusions; and their fallacies" (New Atlantis 183). Within his utopian college and sense-laboratory, he envisions spaces that not only stimulate understanding but simulate and provoke misunderstanding: spaces in which encounters with deceptive stimuli may mislead the intellect and create false knowledge, too. The college is portrayed as hostile to "impostures and lies," yet it is conscious of the potential fallibility of the external senses and conducts experiments within these houses to further man's knowledge of the same (New Atlantis 183). Jonson takes a more (literally and figuratively) dramatic approach to addressing the limitations of the external senses by creating a "House of Deceit" in which playgoers 
expect, and yet still fail, the tests of their senses. He makes this more explicit in the second prologue, added to Epicene after its initial shocked reception and the subsequent offenses drawn out of it by Lady Arabella Stuart. "On forfeit of your selves, think nothing true," he cautions and, integrating himself into the sonic communities of both the playworld and the theatre, he threatens his own judgment upon them: not just for the failure to use their "ear[s] and sight" but the potential failure to think about it afterwards (Pro. 2.7, 6). It is not enough to take in primary sensory information and assume understanding; it must be transmitted to the secondary senses and the information received must be processed and chewed over.

No one sense alone can be trusted, moreover. Jonson demands in the prologues the combination of the primary senses of hearing, seeing, and (metaphorically) consuming, before the secondary senses are brought in: not just imagination, but recollection and rationalization, in order to escape the trap into which Morose has fallen, the misguided privileging of one sense, and the sensory disablement wrought by the excessive noise of the metropolis and the usual directives of the theater. "If obscurity happen[s] through the hearer's or reader's want of understanding," he declares in Timber, "I am not to answer for them, no more than for their not listening or marking; I must neither find them ears nor mind [s]" (62-63). The play thus meditates on London's increasingly noisy expansion and tests the ability of its inhabitants to function as effective auditors within a soundscape of escalating aural assaults (to which they also contribute), while simultaneously experimenting with the dramatic and technical potential of the new Whitefriars performance space.

\section{Notes}


${ }^{1}$ The external senses refer primarily to the five we know today (hearing, sight, smell, taste, and touch); they could also include the sixth sense recognised by early moderns (titillation).

${ }^{2}$ See Botelho; Cockayne, Hubbub; Lanier; Smith, Acoustic World; Stanev.

${ }^{3}$ I am indebted to Nick Holder for this material, which was shared in a private communication and is reproduced with his permission. For his published reconstruction of the Whitefriars theatre see "The First Blackfriars"; "The Second Blackfriars"; "Whitefriars." Thanks are also due to Lucy Munro who discussed her view of the venues with me.

${ }^{4}$ See Berry 113; and Bowers 80.

${ }^{5}$ Concerns had previously been raised about the soundproofing capacity of private theatres, as is attested to by the petition from Lady Russell and her cohorts to the Privy Council to prevent Burbage converting the property at Blackfriars into a theater. The petition complained that "the same playhouse [Blackfriars] is so near the church that the noise of the drums and trumpets will greatly disturb and hinder both the ministers and parishioners in time of divine service and sermons," suggesting a perceived potential for excessive sound-leakage, even though the indoor theaters were more enclosed than their outdoor counterparts (qtd. in B. Smith, Acoustic World 480). ${ }^{6} 1.1 ; 1.2 .11-16 ; 1.3 .28-33 ; 2.2 ; 2.5 .100-26 ; 3.1 ; 3.2 .65-75 ; 3.5 ; 4.1 ; 4.2 .92-104,125-$ $44 ; 4.3 .23-24,45-46 ; 4.4 .12-18 ; 4.5 .109 ; 4.7 .13-19$.

${ }^{7}$ Scholars still debate the role played by Field. Blaine Greteman argues that he played the titular role (138). However, Lucy Munro and Richard Dutton argue that, due to the size and scope of the role, Field played Truewit ("The Whitefriars Theatre" 120; Introduction 8). Dutton posits instead Giles Cary as Epicene, a role he would have doubled with Clerimont's Boy. As Dutton points out, here too the joke would have 
been apparent from the start: "the ambiguities of Clerimont's 'ingle' were intended to prompt the audience to anticipate the reality of Morose's 'wife'" (Introduction 7). Among these ambiguities one must include the instability of the adolescent actor's voice, which may well have deepened when he was not whispering or during moments of "strenuous speaking," and the effeminate but mature complaints rooted in his song.

\section{Works Cited}

Aquinas, St Thomas. Summa Theologica. Translated by the Fathers of the Dominican Province, 1947, Sacred E-Texts, sacred-texts.com/chr/aquinas/summa/index.htm.

Accessed Mar. 24, 2015.

Austern, Linda P. Music in English Children's Drama of the Later Renaissance. Taylor and Francis, 1992.

Bacon, Sir Francis. Sylva Sylvarum: or A Natural Histories in Ten Centuries. London, 1627.

---. New Atlantis. Three Early Modern Utopias, edited by Susan Bruce, Oxford UP, 2008, pp. 149-86.

Bailey, Peter. "Breaking the Sound Barrier: a Historian Listens to Noise." Body and Society, vol. 2, 1996, pp. 49-66.

Baldwin, Carryl L. Auditory Cognition and Human Performance: Research and Applications. CRC P, 2016.

Beranek, Leo. L., and Tim. J. Mellow. Acoustics: Sound Fields and Transducers. Academic Press, 2012. 
Berry, H. "Where Was the Playhouse in Which the Boy Choristers of St. Paul's Cathedral Performed Plays?" Medieval and Renaissance Drama in England, vol. 13, 2001, pp. 101-16.

Bloom, Gina. “'Thy Voice Squeaks': Listening for Masculinity on the Early Modern Stage.” Renaissance Drama, vol. 29, 1998, pp. 39-71.

Bly, Mary. "Playing the Tourist in Early Modern London: Selling the Liberties Onstage.” PMLA, vol. 122, no. 1, 2007, pp. 61-71.

"boisterous, adj." OED Online, Oxford UP, Jun. 2015, oed.com/view/Entry/21037?redirectedFrom=BOISTEROUSNESS\#eid. Accessed Aug. 26, 2015.

"boisterousness, n." OED Online. Oxford UP, Mar. 2017, oed.com/view/Entry/21037?redirectedFrom=BOISTEROUSNESS\#eid. Accessed Mar. 18, 2017.

Botelho, Keith. Renaissance Earwitnesses: Rumour and Early Modern Masculinity. Macmillan, 2009.

Bowers, R. "The Playhouse of the Choristers of Paul's, c. 1575-1608." Theatre Notebook, vol. 54, 2000, pp. 70-85.

Brown, Steve. "The Boyhood of Shakespeare's Heroines: Notes on Gender Ambiguity in the Sixteenth Century." SEL, vol. 30, 1990, pp. 243-63.

Bucholz, Robert O., and Joseph P. Ward. London: A Social and Cultural History, 1550-1750. Cambridge UP, 2012.

Buckley, R. A. The Law of Nuisance. London, 1996.

Burton, Robert. The Anatomy of Melancholy. G. Cundee for Vernor and Hood, 1800. Cavanaugh, William, Gregory C. Tocci, and Joseph A. Wilkes. Architectural Acoustics: Principles and Practice. Wiley and Sons, 2010. 
Clapham, A. W. "The Topography of the Carmelite Priory of London." Journal of the British Archaeological Association, vol. 17, 1910, pp. 15-31.

Cockayne, Emily. "Cacophony, or Vile Scrapers on Vile Instruments: Bad Music in Early Modern English Towns.” Urban History, vol. 29, no. 1, 2002, pp. 35-47.

---. Hubbub: Filth, Noise, and Stench in England, 1600-1770. Yale UP, 2008.

Collier, J. Payne. New Facts Regarding the Life of Shakespeare. Thomas Rodd, 1835.

Crooke, Helkiah. Microcosmographia. London, 1700.

Decamp, Eleanor. “"Thou art like a punie-Barber (new come to the trade) thou pick'st our eares too deepe': Barbery, Ear Wax, and Snip-snaps." The Senses in Early Modern England, 1558-1660, edited by Simon Smith et al, Manchester UP, 2015, pp. 74-90.

Dekker, Thomas. The Dead Tearme. London, 1608.

---. The Seven Deadly Sins of London. Edited by Edward Arber, Unwin Brothers, 1905.

Dutton, Richard, editor. “Appendix C: Jonson's Classical Sources.” Epicene, or The Silent Woman, Manchester UP, 2003, pp. 299-309.

---. Introduction. Epicene, or The Silent Woman, by Ben Jonson, Manchester UP, 2003, pp. 1-108.

Ellinghausen, Laurie. Labour and Writing in Early Modern London, 1567-1667. Ashgate, 2008.

Ermann, Michael. Architectural Acoustics Illustrated. Wiley and Sons, 2015.

Feld, Steven. "Waterfalls of Song: An Acoustemology of Place Resounding in Bosavi, Papua New Guinea." Senses of Place, edited by Steven Feld and Keith H. Basso, School of American Research P, 1996, pp. 3-120. 
Forsyth, Michael. Buildings for Music: The Architect, the Musician, the Listener from the Seventeenth Century to the Present Day. Cambridge UP Archive, 1985.

Gosson, Stephen. The School of Abuse, 1579, and A Short Apologie of The School of Abuse, 1579. Edited by Edward Arber, Alex Murray and Son, 1868.

Gouk, Penelope M. "The Role of Acoustics and Music Theory in the Scientific Work of Robert Hooke.” Annals of Science, vol. 37, 1980, pp. 573-605.

Greteman, Blaine. “Coming of Age on Stage: Jonson's Epicoene and the Politics of Childhood in Early Stuart England.” ELH, vol. 79, no. 1, 2012, pp. 135-60.

Griffin, Aurélie. "Love Melancholy and the Senses in Mary Wroth's Works." The Senses in Early Modern England, 1558-1660, edited by Simon Smith et al., Manchester UP, 2015, pp. 148-64.

Gurr, Andrew. The Shakespearian Playing Companies. Clarendon, 1996.

---. The Shakespearean Stage, 1574-1642. $3^{\text {rd }}$ ed., Cambridge UP, 1992.

Hillebrand, H. N. The Child Actors: A Chapter in Elizabethan Stage History. Russell \& Russell, 1964.

Holder, Nick. "The First Blackfriars." Shakespeare's London Theatreland: Archaeology, History, and Drama, edited by Julian Bowsher, Museum of Archaeology, 2012, pp. 118-26.

---. "The Medieval Friaries of London: a topographical and archaeological history before and after the Dissolution." $\mathrm{PhD}$ Thesis, Royal Holloway, University of London, 2011.

---. "Re: Whitefriars". Received by Briony Frost, Jun. 22, 2015.

---. "The Second Blackfriars." Shakespeare’s London Theatreland: Archaeology, History, and Drama, edited by Julian Bowsher, Museum of Archaeology, 2012, pp. 118-26. 
---. "Whitefriars." Shakespeare's London Theatreland: Archaeology, History, and Drama, edited by Julian Bowsher, Museum of Archaeology, 2012, pp. 118-26.

Howard, David, and Jamie Angus. Acoustics and Psychoacoustics. CRC P, 2013.

Jackson, J. A. "'On forfeit of your selves, think nothing true': Self-Deception in Ben Jonson's Epicoene." Early Modern Literary Studies, vol. 10, no. 1, 2004, pp. 21-28, purl.oclc.org/emls/10-1/jackjons.htm. Accessed Apr. 3, 2015.

Jardine, Lisa. Still Harping on Daughters. Harvester P, 1983.

Johnson, Samuel. A Dictionary of the English Language. London, 1755.

Jonson, Ben. "XIV: To Mr. John Fletcher, Upon His Faithful Shepherdess." Underwoods: Consisting of Divers Poems. The Works of Ben Jonson, edited by W. Gifford, Phillips, Sampson, and Co, 1853, p. 815.

---. Epicene. English Renaissance Drama: A Norton Anthology, edited by David Bevington, et al, Norton, 2002, pp. 775-860.

---. Poetaster. Edited by Tom Cain, Manchester UP, 1996.

---. Timber, or Discoveries Made upon Men and Matter Edited by F. E. Schelling, Ginn and Company, 1892.

---. Volpone, or The Fox. English Renaissance Drama: A Norton Anthology, edited by David Bevington, et al, Norton, 2002, pp. 679-773.

Karim-Cooper, Farah. "The Sensory Body in Shakespeare's Theatres." The Five Senses in Medieval and Early Modern England, edited by A. Kern-Stähler et al., Brill, 2016, pp. 269-85.

Keenan, Siobhan. Renaissance Literature. Edinburgh UP, 2008.

Kindig, Steve. "Room Acoustics for Home Audio.” Crutchfield Acoustics, Crutchfield, 2017, crutchfield.com/S- 
ZTjKhWUnvDM/learn/learningcenter/home/speakers_roomacoustics.html. Accessed Dec. 23, 2015.

Lanier, Douglas. "Masculine Silence: Epicoene and Jonsonian Stylistics." College Literature, vol. 21, 1994, pp. 1-18.

Levine, Laura. Men in Women's Clothing: Anti-Theatricality and Effeminization, 1579-1642. Cambridge UP, 1994.

Long, Marshall. Architectural Acoustics. Academic P, 2014.

MacIntyre, Jean. "Production Resources at the Whitefriars Playhouse, 1609-1612."

Early Modern Literary Studies, vol. 2, no. 3, 1996, pp. 1-35, purl.oclc.org/emls/023/maciwhit.html. Accessed Aug. 17, 2015.

Merrit, J. F. The Social World of Early Modern Westminster: Abbey, Court and Community, 1525-1640. Manchester UP, 2005.

Mullaney, Steven. The Place of the Stage: License, Play, and Power in Renaissance England. U of Michigan P, 1995.

Munro, Lucy. Children of the Queen's Revels: A Jacobean Theatre Repertory. Cambridge UP, 2005.

---. "The Whitefriars Theatre and the Children's Companies." Ben Jonson in Context, edited by Julie Sanders, Cambridge UP, 2010, pp. 116-123.

Nashe, Thomas. Nashes Lenten Stuffe. London, 1599.

North, Roger. Of Building: Roger North's Writings on Architecture, edited by H. Colvin and J. Newman, Oxford UP, 1981.

Peacham, Henry. Coach and Sedant, Pleasantly Disputing for Place and Precedence, the Brewers-cart Being Moderator. London, 1636.

Rossing, Thomas. Springer Handbook of Acoustics. Springer, 2015. 
Schafer, R. Murray. The Soundscape: Our Sonic Environment and the Tuning of the World. Destiny Books, 1994.

Scott, Sarah. "The Architecture of Sound." Azure, vol. 21, 2005, pp. 1-6.

Shakespeare, William. Hamlet. Edited by Harold Jenkins, Bloomsbury, 2003.

Shakespeare, William, and John Fletcher. Henry VIII. Edited by Gordon McMullan, Bloomsbury, 2002.

Sherman, Stuart. Telling the Time: Clocks, Diaries, and English Diurnal Form, 16601785. U of Chicago P, 1996.

Smith, Bruce. The Acoustic World of Early Modern England: Attending to the OFactor. Chicago UP, 1999.

---. The Key of Green: Passion and Perception in Renaissance Culture. U of Chicago P, 2010.

Smith, Irwin. Shakespeare's Blackfriars Playhouse: its History and Design. New York UP, 1964.

Smith, Simon. “'I See No instruments, nor Hands that Play': Antony and Cleopatra and Visual Musical Experience." The Senses in Early Modern England, 1558-1660, edited by Simon Smith et al., Manchester UP, 2015, pp. 167-84.

Stanev, Hristomir. Sensory Experience and the Metropolis on the Jacobean Stage, 1603-1625. Ashgate, 2014.

Steele, Kerry. "Terra Incognita: A Theoretical Reconstruction of the Whitefriars Stage.” PhD Thesis, Shakespeare Institute, 2009.

Teague, Frances, "Ben Jonson's Stagecraft in Epicoene." Renaissance Drama, vol. 9, 1978, pp. 175-92.

Tosh, Will, and Simon Smith. "Music in the Early Modern Indoor Playhouse." Research in Action, Jul. 2, 2015, Sam Wanamaker Playhouse, London. Workshop. 
Truax, Barry. Acoustic Communication. Vol. 1, Ablex Publishing, 1984.

Wenger Corporation. Acoustic Problems and Solutions for Rehearsal and Practice Spaces. Wenger, 2000.

Wickham, Glynne, William Ingram, and Herbert Berry. English Professional Theatre, 1530-1660. Cambridge UP, 2000.

Wilkins, John. Mercury, or the Secret and Swift Messenger. London, 1641.

“windfucker, n." OED Online, Oxford UP, September 2016, oed.com/view/Entry/229219?redirectedFrom=windfucker\#eid. Accessed Apr. 10, 2017.

Wolfe, Jessica. Humanism, Machinery and Renaissance Literature. Cambridge UP, 2009.

Yiu, Mimi. "Sounding the Space between Men: Choric and Choral Cities in Ben Jonson's Epicoene; Or, the Silent Woman.” PMLA, vol. 122, no. 1, 2007, pp. 72-88.

---. “Architecture.” Ben Jonson in Context, edited by Julie Sanders, Cambridge UP, 2010, pp. 304-13.

Zucker, Adam. "London and Urban Space." Ben Jonson in Context, edited by Julie Sanders, Cambridge UP, 2010, pp. 97-106. 